\title{
The Effect of Risk Dimension on Tourist Loyalty: A Mediating Role of Political Stability
}

\author{
Edais Shehab, Ahmad Puad Mat Som
}

To Link this Article: http://dx.doi.org/10.6007/IJARBSS/v11-i5/9676

DOI:10.6007/IJARBSS/v11-i5/9676

Received: 01 April 2021, Revised: 26 April 2021, Accepted: 10 May 2021

Published Online: 21 May 2021

In-Text Citation: (Shehab \& Som, 2021)

To Cite this Article: Shehab, E., \& Som, A. P. M. (2021). The Effect of Risk Dimension on Tourist Loyalty: A Mediating Role of Political Stability. International Journal of Academic Research in Business and Social Sciences, 11(5), 386-396.

\section{Copyright: (c) 2021 The Author(s)}

Published by Human Resource Management Academic Research Society (www.hrmars.com)

This article is published under the Creative Commons Attribution (CC BY 4.0) license. Anyone may reproduce, distribute, translate and create derivative works of this article (for both commercial and non-commercial purposes), subject to full attribution to the original publication and authors. The full terms of this license may be seen at: http://creativecommons.org/licences/by/4.0/legalcode

Vol. 11, No. 5, 2021, Pg. 386 - 396

Full Terms \& Conditions of access and use can be found at http://hrmars.com/index.php/pages/detail/publication-ethics 


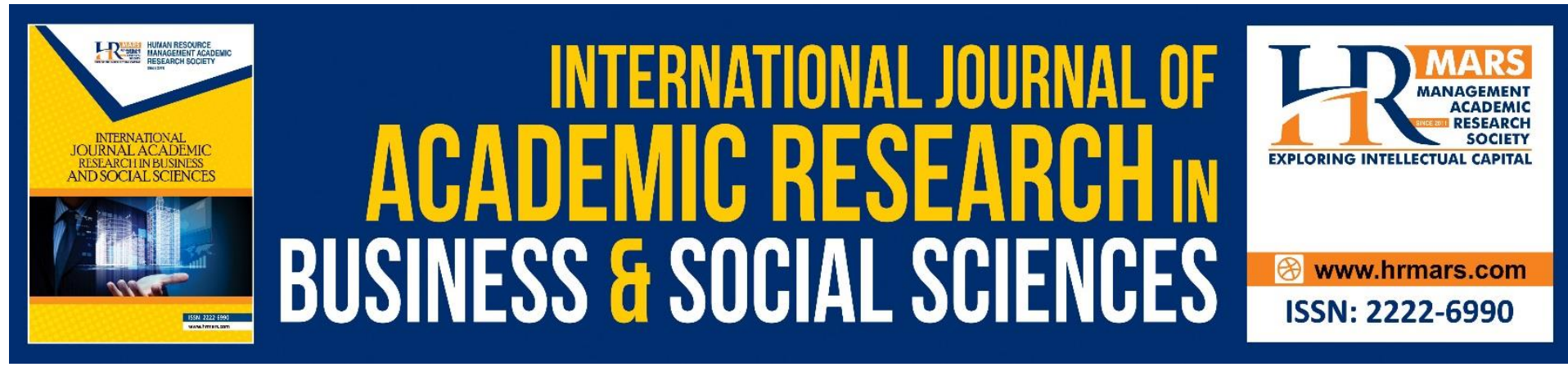

\title{
The Effect of Risk Dimension on Tourist Loyalty: A Mediating Role of Political Stability
}

\author{
Edais Shehab ${ }^{1,2}$, Ahmad Puad Mat Som ${ }^{1}$ \\ ${ }^{1}$ Faculty of Applied Social Sciences, Universiti Sultan Zainal Abidin, Malaysia, ${ }^{2}$ Faculty of \\ Tourism \& Hotel, Modern University College, Palestine \\ Email: sharly@hotmail.co.il, puadms@unisza.edu.my
}

\begin{abstract}
Perceived risk is a threat to the successful marketing in the tourism industry, and uncertain perceptions of risk can negatively impact on tourist behaviour at a tourism destination. The objective of this study is of two-folds: first, to investigate the impact of Israel's risk on tourist loyalty in Jerusalem, and to examine the mediating effect of political stability on the relationship between Israel's risk and tourist loyalty. A questionnaire design was adapted from previous studies and 384 survey forms were distributed to tourists who visited religious sites in Jerusalem. In this study, cluster sampling was utilized. The statistical data was described and analyzed, and the logical hypotheses were analyzed using the "IBM SPSS AMOS Package 22.0". The results of the study showed that political stability partially mediates the effects on the relationship between Israel's risk and tourist loyalty. A direct path is still significant in this study. Thus, the research suggests that perceived risk must be eliminated or significantly reduced to encourage tourists to revisit Jerusalem, in line with the consistent growth of the tourism industry around the world.
\end{abstract}

Keywords: Israel's Risk, Tourist Loyalty, Political Stability, Palestine, Jerusalem.

\section{Introduction}

Palestine is one of the most famous tourist attractions in the world due to its religious, historical and cultural importance as the cradle of three religions and the inheritance of ancient civilizations throughout the ages. In addition to its geographical location and strategic excellence, Palestine's importance derives from its history as a holy place for Islam, Christianity, and Judaism (Isaac, Hall \& Higgins-Desbiolles, 2016). It is one of the oldest continuously inhabited areas in the world (Reiter, Eordegian \& Khalaf, 2001). However, commencing the twentieth century, Palestine faced a catastrophe in its political and social conditions. This is represented by the emergence of the Israeli state in 1948 and occupation of West Bank, Gaza Strip and East Jerusalem in 1967 (Beinin and Hajjar, 2014). The advent of these tragic calamities has affected the socio-economical life of the Palestinians, many of whom have become refugees displaced to Jordan, Syria, and Lebanon (Burton, 2016). Jerusalem has a unique place for Muslims and Christians due to the existence of the Al-Aqsa Mosque and the Church of the Holy Sepulcher. The occupied Jerusalem is surrounded by illegitimate settlements, blockade, encompassed by various check-points, encircled by the 
"Apartheid Wall" and has been illegally annexed to Israel (Isaac, Hall \& Higgins-Desbiolles, 2015; Timothy, 2018).

Either for religious pilgrimage or tourism visitation, Jerusalem has attracted a substantial number of visitors to the country. The major challenge facing tourists is the safety and security of location, convenience for tourist, service consumption experience, emotional attachment, risks, trust and perception of destination image (Dai, Haried \& Salam, 2011). The issues that affect Jerusalem as a tourism place are multi-dimension just like any tourism location; however, this study focuses on the loyal behavior of those who had visited Jerusalem, those who wish to visit someday and those who hold some perception about the sites and locations of the place.

- $\quad$ This study is principally aimed to examine critically and investigate the effect of Israel risk on the tourist loyalty in Jerusalem, mediated by political stability.

\section{Literature Review}

\section{Relationship between Perceived Risk and Tourist Loyalty}

"Perceived risk involves uncertainty and the negative consequences of buying a service" (Dowling and Staelin, 1994). Mitchell (1998) also considers the performance risk as a substitute for the whole risk factor, which involves the combinations of total losses. This current study focuses on the performance risk evaluated as the ultimate consumers are often conscious about the performances of the services, which are attributed to the heterogeneity and intangibility. According to $\mathrm{Hu}$ (2011), perceived risks have a significant positive association with customers' loyalty.

The extent of various risks attached to the purchasing services and goods have also linked with customers' loyalty development (Lai-Ming Tam, 2012). In the same vein, the consumers cling with the products and services that are known to them and are compatible to minimize the incurring redundant risks (Currás-Pérez, Ruiz-Mafé and Sanz-Blas, 2013). Therefore, if the risk is considered as perceived at low level to initiate a first purchase attempt, the loyalty will begin to develop as an additional procedure, and the purchase routine will continue to fully satisfy the existing consumers' needs by reducing the risk (Flavián and Guinalíu, 2006). In this context, different studies based on evidence have demonstrated that the received experiential information from the repeated consumptions enhance the future purchasing tendency (i.e., positive feedback). In another context, as the perceived risk decreases, customers' loyalty conversely increases. Accordingly, the following hypothesis is proposed:

- $\quad H 1$ : Israel's risk has a negative influence on tourists' loyalty.

\section{The Relationship between Perceived Risk and Political Stability}

The study is conducted to examine the impacts of "political violence" on tourism. Neumayer (2004) concluded that despite the aggressive conflict, the "human rights violations" negatively affect the tourism industry. Furthermore, the perceived risk related to tourists, connected with the dispute, facing the travel hurdles, or unable to utilize the destination's perceptions resulting from damage or safety measures, show a considerable obstacle to tourism. Despite this, according to Hunter-Jones, Jeffs and Smith (2008), the researcher concluded that tourists might also ignore destinations in the state of crisis because they relate tours with such places with the support of conflict. In such a context, it is expected that lack of stability of socio-economic conditions and political aspects of the destination may easily discourage the tourists' inflow (Richter, 1999). This uncovers the challenges and the 
complexity produces in the evaluation of risks attached to insecure destination. Thus, the following hypothesis is proposed:

- $\quad \mathrm{H} 2$ : Israel's risk has a negative influence on political stability

\section{The Relationship between Political Stability and Tourist Loyalty}

Political instability is considered as a condition, where the political authority, social structure and the governance style are highly challenged (Hall and O'Sullivan, 1996). The political structure needs to accept those challenges to attain stability again. But, when the force to change is dissatisfied within the political structure, the adoption of illegitimate actions, i.e. violence, unauthorised protests or civil war may occur to trigger the changes. The political structure then becomes unstable. The perception of the stable political structure is favourably attached to economic and social development (Przeworski, Alvarez and Cheibub, 2000), although there are very few agreements on how such situations influence the flow of economic progress.

The benefit of political stability for a specific regime is not unexpected. Because the regime style is autocratic, various influential elites exist to satisfy and extract the loyalty to stabilize the power as conceptually discussed in the following conceptual framework (Sandler, 2015). Thus, the following hypothesis is proposed:

- H3: Political stability has a positive influence on tourist loyalty.

\section{The Mediating Effect of Political Stability on the Relationship between Israel's Risk and Tourist Loyalty}

Despite the direct connection between Israel's risk and tourist loyalty, various studies have investigated the association via the mediating role of various other prominent factors, i.e. political stability. Thus, due to the expected complication in the indirect association, which varies considerably across various studies, the overall impact of mediating factors was measured and implemented in the current study. The direct connection between Israel's risk and tourist loyalty will be empirically compared with the overall influence, which is the total of indirect and direct effects. This is among the few studies that examines the impact of political stability on customer loyalty, specifically in Jerusalem, Palestine. It is worth mentioning that there is no sufficient studies and literature to support this hypothesis.

- H4: Political stability mediates the relationships between Israel's risk and tourist loyalty.

\section{Conceptual Framework}

The underpinning theory (Theory of Risk Object) and the thorough review of literature, the relevant study variables help in developing the conceptual framework. The research framework is the relational structure to hypothesize the expected association between Israel's risk and tourist loyalty along with the role of political stability (mediator) on the association between Israel's risk and tourist loyalty in Jerusalem. Based on the above arguments, the current study has utilized "Theory of Risk Object" to describe the expected research framework, as shown in Figure 1. 


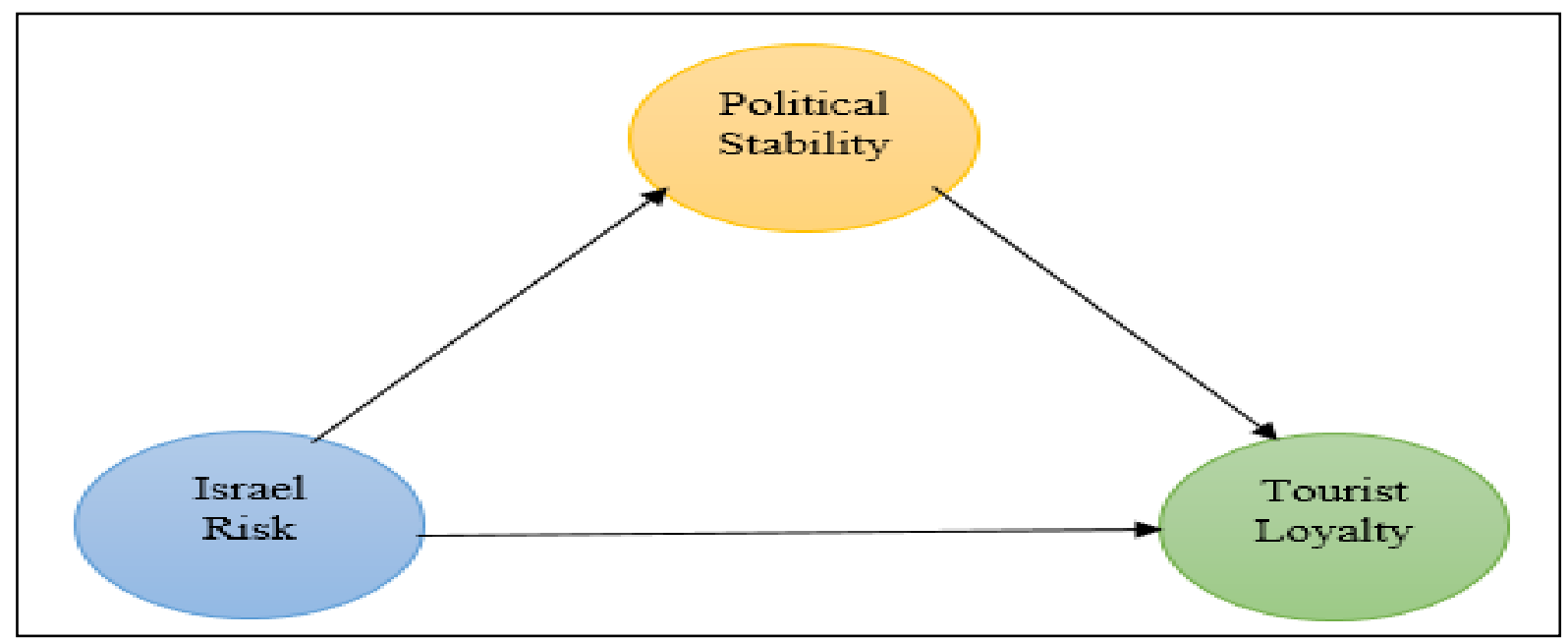

Figure 1: Conceptual framework

\section{Research Methodology}

The current study aims to examine the connection of Israel's risk and tourist loyalty with political stability as the mediating factor. The present study employs a quantitative technique as the most suitable research method. The quantitative technique covers the system of inquisition by associating among specific variables that can be summarized into statistical values and will be able to implement for a particular population (Finnerty, Kucherbaev, Tranquillini \& Convertino, 2013). This study used the descriptive method and measurement via a survey. Questionnaires were personally sent to tourists in Jerusalem and distributed in four places (Qubbat As-Sakhra, Al-Masjid Al-Aqsa, Church of the Holy Sepulchre, and Tomb of the Virgin Mary). Cluster sampling was used in this study, but randomly. Respondents were randomly chosen as it provided for a true cross-section of the population; a total of 384 completed survey forms was collected. As the study adopted the quantitative technique, the statistical examination was done via "SPSS 22.0" and "IBM AMOS 22.0". This analytical tool is accurate and extensively employed in different research works in social sciences. The study mainly depends on the causal association between the variables, which shows the association between the variables that have been investigated.

\section{Results}

\section{Statistical Model}

Before developing a statistical model and using SEM, the study requires to find the validity of the developed model to examine the unidimensionality, reliability and validity (Awang, 2015). Unidimensionality is a means that can be achieved as a "factor loading" for total items that are considerably positive with a mini value equals to 0.6 . The "construct validity" is attained as the model appropriateness for the technical measuring model meeting three model fit categories. Furthermore, the "discriminant validity" is reached as the overall constructs are not correlated. The "convergent validity" is also attained, as the numerical value of "Average Variance Extracted (AVE)" meets the minimum numerical value of the 0.5 (Hair, Hult, Ringle \& Sarstedt, 2014). The "construct reliability" is achieved, where the numerical values of the "Composite Reliability (CR)" and "Average Variance Extracted (AVE)" touched the minimum numerical value of about 0.6 and the 0.5 respectively (Hoque, Awang, Muda \& Alleh, 2018). The "internal reliability" among all the items is accomplished as the numerical value of the "Cronbach Alpha" reaches the minimum numerical value of 0.7 (Fornell and Larcke, 1981). The fitness indexes are shown in Figure 2. 
Figure 2: Analytical model

\section{Goodness of Fit Indices of Measurement Model}

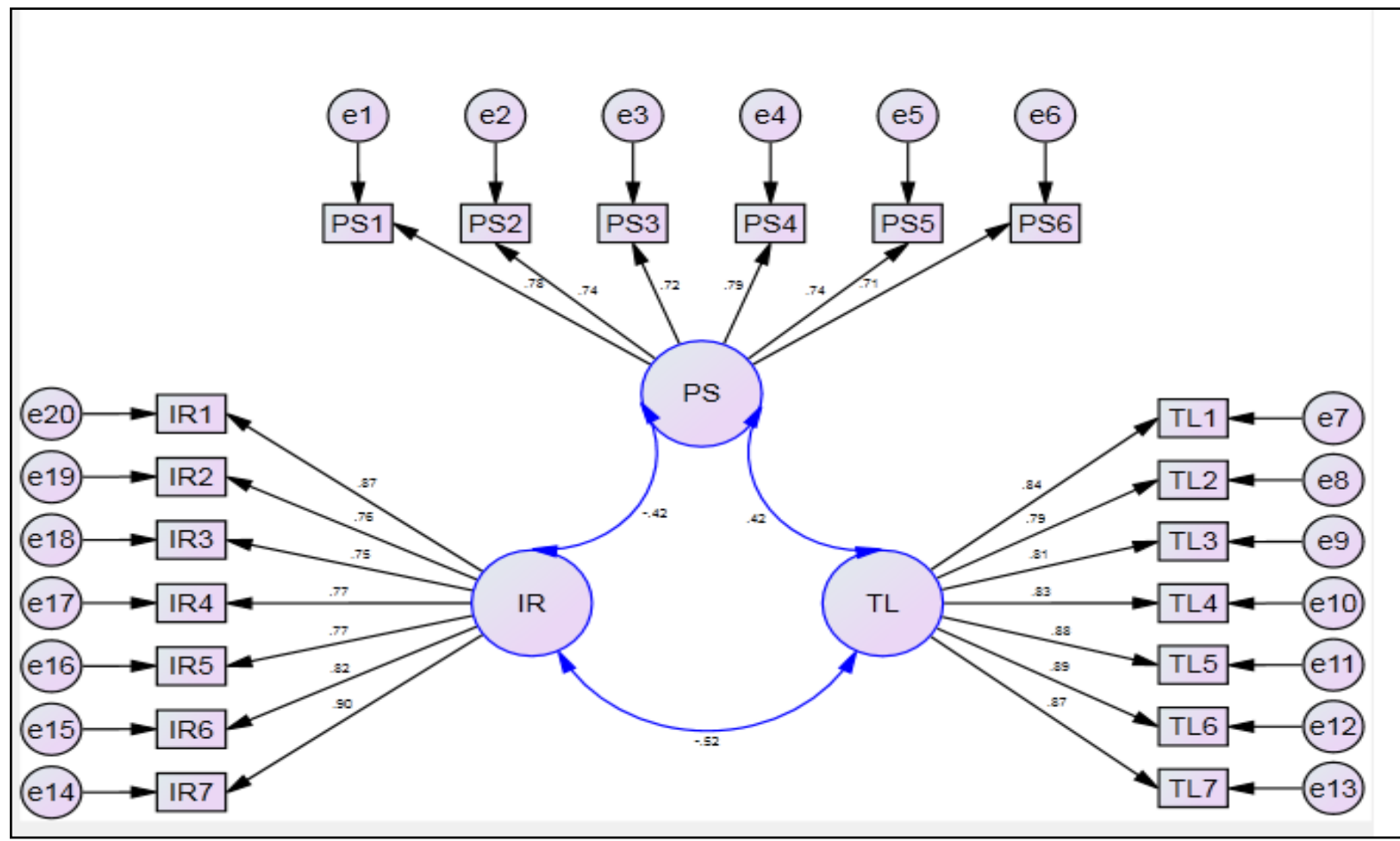

The results regarding the measurement model indicated fit indices. The commonly used GOF

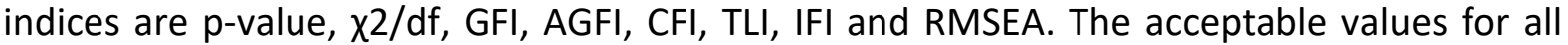
these indices are presented below in the table along with their references.

The fitness indexes show the analysis model of the four latent constructs (Israel's risk, political stability and tourist loyalty) have achieved the requirement for the "construct validity".

Table 1: GOF Indices (Measurement Model)

\begin{tabular}{lcll}
\multicolumn{1}{c}{ Fit index } & $\begin{array}{c}\text { Modified } \\
\text { Model }\end{array}$ & $\begin{array}{c}\text { Recommended } \\
\text { values }\end{array}$ & \multicolumn{1}{c}{ Source } \\
\hline $\mathrm{Df}$ & 804 & & \\
\hline $\mathrm{CMIN}\left(\mathrm{X}^{2}\right)$ & 1407.06 & & Forza \& Filippini (1998) \\
\hline $\mathrm{p}$-value & 0.000 & $>0.05$ & Bagozzi \& Yi (1988) \\
\hline$\chi^{2} / \mathrm{df}$ & 1.75 & $\leq 5.00$ & Forza \& Filipini (1998) \\
\hline $\mathrm{GFI}$ & 0.855 & $\geq 0.80$ & Chau \& Hu (2001) \\
\hline $\mathrm{AGFI}$ & 0.838 & $\geq 0.80$ & $\begin{array}{l}\text { Bagozzi \& Yi (1988); Byrne, } \\
\text { 1998 }\end{array}$ \\
\hline $\mathrm{CFI}$ & 0.959 & $\geq 0.90$ & Hair et al., (2006); Ho, (2006) \\
\hline TLI & 0.957 & $\geq 0.90$ & Hair et al., (2006); Ho, (2006) \\
\hline IFI & 0.960 & $\geq 0.90$ & Schumacker \& Lomax (2010) \\
\hline RMSEA & 0.044 & $\leq 0.10$ &
\end{tabular}


The values of the factor loading for each item with the "Cronbach Alpha", "CR" and "AVE" for each construct are shown in Table 2, and it shows total latent constructs (Israel's risk, political stability and tourist loyalty) have achieved the "convergent validity", "construct reliability" and "internal reliability".

Table 2: Composite Reliability and Average Variance Extracted

\begin{tabular}{|c|c|c|c|c|c|}
\hline \multirow[t]{2}{*}{ Constructs } & \multirow[t]{2}{*}{ Items } & \multirow{2}{*}{$\begin{array}{l}\text { Internal } \\
\text { Reliability } \\
\text { (Alpha) }\end{array}$} & \multicolumn{3}{|c|}{ Convergent Validity } \\
\hline & & & $\begin{array}{l}\text { Factor } \\
\text { Loadings }\end{array}$ & $\begin{array}{l}\text { Average } \\
\text { Variance } \\
\text { Extracted } \\
\text { (above } 0.5 \text { ) }\end{array}$ & $\begin{array}{l}\text { Composite } \\
\text { Reilability } \\
\text { (above } 0.6 \text { ) }\end{array}$ \\
\hline \multirow[t]{7}{*}{ ISRAELI_RISK } & IR1 & 0.927 & 0.864 & 0.650 & 0.928 \\
\hline & IR2 & & 0.765 & & \\
\hline & IR3 & & 0.749 & & \\
\hline & IR4 & & 0.767 & & \\
\hline & IR5 & & 0.774 & & \\
\hline & IR6 & & 0.82 & & \\
\hline & IR7 & & 0.893 & & \\
\hline \multirow[t]{7}{*}{ TOURIST_LOYALTY } & TL1 & 0.945 & 0.84 & 0.713 & 0.945 \\
\hline & TL2 & & 0.792 & & \\
\hline & TL3 & & 0.807 & & \\
\hline & TL4 & & 0.83 & & \\
\hline & TL5 & & 0.876 & & \\
\hline & TL6 & & 0.891 & & \\
\hline & TL7 & & 0.868 & & \\
\hline \multirow[t]{6}{*}{ POLITICAL_STABILITY } & PS1 & 0.883 & 0.782 & 0.560 & 0.884 \\
\hline & PS2 & & 0.742 & & \\
\hline & PS3 & & 0.718 & & \\
\hline & PS4 & & 0.79 & & \\
\hline & PS5 & & 0.74 & & \\
\hline & PS6 & & 0.715 & & \\
\hline
\end{tabular}

The "discriminant validity" is evaluated by using correlation and "discriminant validity index". Table 3 indicates that the "Discriminant Validity Index Summary" and the diagonal values in the same table are the square root of AVE for the relative constructs while other numerical values show the correlational association between the constructs. The "discriminant validity" is attained for the model because the diagonal values are higher than any values in their rows, and columns (Awang, 2015).

Table 3: Discriminant Validity Index Summary

\begin{tabular}{l|r|r|r|r|r}
\hline & \multicolumn{1}{l|}{ CR } & \multicolumn{1}{l|}{ AVE } & \multicolumn{1}{l|}{ IR } & \multicolumn{1}{l}{ TL } & \multicolumn{1}{l}{ PS } \\
\hline ISRAELI_RISK & 0.928 & 0.650 & $\mathbf{0 . 8 0 6}$ & & \\
\hline TOURIST_LOYALTY & 0.945 & 0.713 & -0.525 & $\mathbf{0 . 8 4 4}$ & \\
\hline POLITICAL_STABILITY & 0.884 & 0.560 & -0.416 & 0.417 & $\mathbf{0 . 7 4 8}$ \\
\hline
\end{tabular}

The correlation value of latent constructs IR and PS is -0.416 ; the correlation value of latent constructs IR and TL is -0.525 , and correlation value of PS and TL is 0.417 . 
The inter-correlations between all constructs of the model are below threshold 0.85 as recommended by Kline (2005). Furthermore, as shown in the above table, the correlations were less than the square root of the average variance extracted by the indicators, which demonstrates good discriminant validity between these factors (Kline, 2005). Upon examining goodness to fit of data, convergent validity and discriminant validity of the modified measurement model, it can be concluded that the final modified measurement scale to assess the constructs and their relative items were reliable and valid.

\section{Structural Model}

Table 4 illustrates the three hypotheses $(\mathrm{H} 1, \mathrm{H} 2$ \& $\mathrm{H} 3)$ are supported. The direct relationships of the hypotheses were tested using structural equation modelling. As shown in the table, all paths of direct relationships are found to be supported as their $p$-values are below 0.05 , which means that the connections are significant.

Table 4: Results of Direct Hypotheses

\begin{tabular}{lr|r|r|r}
\hline HYPOTHESES & Estimate & P-value & $\begin{array}{l}\text { Bootstrapped } \\
\text { (P-value) }\end{array}$ & Label \\
\hline $\begin{array}{l}\text { H1:Israel Risk } \rightarrow \text { Tourist } \\
\text { Loyalty }\end{array}$ & -.265 & .000 & .000 & Supported \\
\hline $\begin{array}{l}\text { H2:Israel Risk } \rightarrow \text { Political } \\
\text { Stability }\end{array}$ & -.214 & .000 & .000 & Supported \\
\hline $\begin{array}{l}\text { H3:Political Stability } \rightarrow \text { Tourist } \\
\text { Loyalty }\end{array}$ & .208 & .004 & .005 & Supported \\
\hline
\end{tabular}

\section{Test of Mediation}

Figure 3: Standardized Regression Weights for the Model

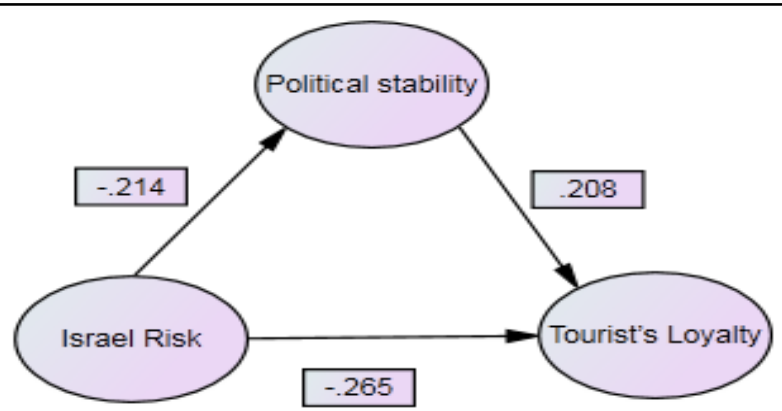

Indirect effect $=-0.214 \times 0.208=-0.044$ and direct effect $=-0.265$. So, indirect effect $>$ direct effect and both indirect paths (i.e., IR to PS and PS to TL) are significant. Moreover, direct path is still significant. Therefore, partial mediation occurs.|

Table 5: Bootstrapping of Mediation Effect

\begin{tabular}{l|r|r|l}
\hline HYPOTHESES & $\begin{array}{l}\text { ESTIMATE } \\
\text { (INDIRECT EFFECT) }\end{array}$ & $\begin{array}{l}\text { Bootstrapped } \\
\text { P-value }\end{array}$ & Label \\
\hline $\begin{array}{l}\text { H4: Israel Risk } \rightarrow \text { Political } \\
\text { stability } \rightarrow \text { Tourist's Loyalty }\end{array}$ & -0.044 & 0.005 & Supported \\
\hline
\end{tabular}


The results show that political stability mediates the relationship between tourist trust, Israel's risk and tourist loyalty since both indirect paths are significant, and the indirect effect is higher than the direct impact as well as the direct impact is still significant after mediator enters the model.

\section{Confirming the Mediation Result through Bootstrapping}

Awang (2015) argue that the usage of re-sampling procedure which is known as bootstrapping to reconfirm the hypothesis testing result of the indirect effect. Based on the bootstrapping results in Table 6, it is evident that political stability partially mediates the relationship between Israel's risk and tourist loyalty. Consequently, the $\mathrm{H} 4$ of this study which posited that political stability mediates the relationship Israel's risk on tourist loyalty is also supported by the data of this study.

Table 6: Summary of Bootstrapping Result of Mediation Effect

\begin{tabular}{|c|c|c|}
\hline & Indirect Effect & direct Effect \\
\hline $\begin{array}{l}\text { Bootstrapping } \\
\text { Results }\end{array}$ & -0.044 & -.265 \\
\hline $\begin{array}{l}\text { Does mediation } \\
\text { occur? }\end{array}$ & \multicolumn{2}{|c|}{$\begin{array}{l}\text { The mediation occurs since the indirect effect is greater than } \\
\text { direct effect. }\end{array}$} \\
\hline $\begin{array}{l}\text { Bootstrapping } p- \\
\text { value }\end{array}$ & 0.005 & 0.000 \\
\hline Results & Significant & Significant \\
\hline Type of Mediation & \multicolumn{2}{|c|}{ Partial Mediation since the direct is still significant. } \\
\hline
\end{tabular}

\section{Conclusion}

The study highlights key ingredients to investigate the influence of Israel's risk as an independent variable on tourist loyalty and examine how they are mediated by political stability in Jerusalem. The resulting framework will provide an understanding of the factors affecting tourists' loyalty in Palestine. Finally, this study would further contribute to the adoption of new policies to bridge the gap still existing in the tourism industry in Jerusalem in terms of best practices. In this study, the researcher tries to underscore how political stability can interact in the relationship between Israel's risk and tourist loyalty in Jerusalem.

\section{Theoretical Implication}

The present study specifically extends literature on Israeli risk by examining their effect on political stability and tourist loyalty. Such relationship indicates the requirement to shed light on whether or not the variables improve tourist loyalty in the tourism industry. Literature argues that the measure of Israeli risk is reflective of the overall evaluation of visitation to Jerusalem, and thus, they are determinants of future relationships. The results support the extent of literature through negative influence of the independent variable on mediating variable and the dependent variables, in line with the theory of risk object that underpinned this study.

\section{References}

Isaac, R., Hall, M., \& Higgins-Desbiolles, F. (2016). The Politics and Power of Tourism in Palestine. Routledge Publishers, London. 
Reiter, Y., Eordegian, M., \& Khalaf, M. A. (2001). Jerusalem's Religious Significance. PalestineIsrael Journal of Politics, Economics, and Culture, 8(1), 12-19.

Beinin, J., \& Hajjar, L. (2014, February). Palestine, Israel and the Arab-Israeli Conflict. Middle East. The Middle East Research and Information Project, 1-16. Retrieved from http://web.stanford.edu/group/sper/images/Palestine-Israel_Primer_MERIP.pdf.

Burton, G. (2016). Building ties across the Green Line: the Palestinian 15 March youth movement in Israel and occupied Palestinian territory in 2011. Third World Quarterly, 38(1), 169-184. doi:10.1080/01436597.2015.1135398

Timothy, D. J. (2018). Routledge Handbook on Tourism in the Middle East and North Africa. Routledge Publishers, Abingdon.

Dai, H., Haried. P., \& Salam, A. (2011). Antecedents of Online Service Quality, Commitment and Loyalty, Journal of Computer Information Systems, 52(2), 1-11. doi: 10.1080/08874417.2011.11645535

Dowling, G., \& Staelin, R. (1994). A model of perceived risk and intended risk-handling activity, Journal of consumer research, 21(1), 119-134.

Mitchell, V. W. (1998). A role for consumer risk perceptions in grocery retailing, British Food Journal, 100(4), 171-183.

$\mathrm{Hu}, \mathrm{Y}$. J. (2011). Exploring the relationship between customer involvement, brand equity, perceived risk and customer loyalty: The case of electrical consumer products, International Journal of Organizational Innovation Online , 4(1), 111-127.

Lai-Ming, T. J. (2012). The moderating role of perceived risk in loyalty intentions: an investigation in a service context, Marketing Intelligence \& Planning, 30(1), 33-52.

Currás-Pérez, R., Ruiz-Mafé, C., \& Sanz-Blas, S. (2013). Social network loyalty: evaluating the role of attitude, perceived risk and satisfaction, Online Information Review, 37(1), 6182.

Flavián, C., \& Guinalíu, M. (2006). Consumer trust, perceived security and privacy policy: three basic elements of loyalty to a web site, Industrial Management and Data Systems, 106(5), 601-620.

Neumayer, E. (2004). The impact of political violence on tourism: Dynamic cross-national estimation, Journal of conflict resolution, 48(2), 259-281.

Hunter-Jones, P., Jeffs, A., \& Smith, D. (2008). Backpacking your way into crisis: an exploratory study into perceived risk and tourist behaviour amongst young people, Journal of Travel and Tourism Marketing, 23(2-4), 237-247.

Richter, L. K. (1999). After political turmoil: The lessons of rebuilding tourism in three Asian countries, Journal of Travel Research, 38(1), 41-45.

Hall, C. M., \& O'Sullivan, V. (1996). Tourism, political stability and violence. Tourism, crime and international security issues, 105-121. Wiley Publishers, New York.

Przeworski, A., Alvarez, M., \& Cheibub, J. A. (2000). Democracy and Development: Political Institutions and Well-Being in the World, 1950-1990, Cambridge University Press, Cambridge, UK.

Sandler, T. (2015). Terrorism and counterterrorism: an overview, Oxford Economic Papers, 67(1), 1-20.

Finnerty, A., Kucherbaev, P., Tranquillini, S., \& Convertino, G. (2013). Keep it simple: reward and task design in crowdsourcing. In Proceedings of the Biannual Conference of the Italian Chapter of SIGCHI (pp. 1-4).

Awang, Z. (2015). SEM made simple: A Gentle Approach to Learning Structural Equation Modeling. Bandar Baru Bangi: MPWS Rich Publications. 
Hair, J. F., Hult, G. T., Ringle, C. M., \& Sarstedt, M. (2014). A Primer on Partial Least Squares Structural Equation Modelling. Thousand Oaks, California: SAGE Publications.

Fornell, C., \& Larcke, R. D. F. (1981). Structural equation models with unobservable variables and measurement error: Algebra and statistics, Journal of Marketing Research, 18(3), 328- 388.

Kline, R. B. (2005). Methodology in the social sciences. Principles and practice of structural equation modeling (2nd ed.). Guilford Press, New York. 